\title{
Perancangan Desain Interior Creative Hub dengan Pendekatan Communal Space
}

\author{
Naufal Aziz A.W. ${ }^{1}$, Hendi Anwar ${ }^{2}$, Dea Aulia W. ${ }^{3}$ \\ 1,2,3 Jurusan Desain Interior, Fakultas Industri Kreatif, Universitas Telkom, Bandung \\ muhammadcing@gmail.com ${ }^{1}$, hendianwar333@gmail.com² ${ }^{2}$ dea_aw@hotmail.com ${ }^{3}$
}

\begin{abstract}
ABSTRAK
"Salah satu hal yang harus diperhatikan oleh kota adalah kenyataan bahwa talenta menguatkan ekonomi, sedangkan diservitas dan kebutuhan menarik talenta untuk datang" (Florida, 2005:139). Berdasarkan hasil survey dalam bentuk kuisioner yang ditujukan pada remaja aktif (18th-24th) di kota Bandung, dapat disimpulkan bahwasannya seorang remaja memiliki ketertarikan dalam melakukan interaksi untuk memenuhi kebutuhan sosisalnya. Pengguna yang dimaksud pada perancangan ini adalah Gen $\mathrm{Z}$ pada usia produktivitas (remaja). Generasi Z pada usia tersebut memiliki karater antara lain lebih tidak fokus, multitasking, lebih individual, berfikiran lebih terbuka, tertarik untuk berinteraksi, lebih reliabilitas, memiliki cara yang lebih effisien (non-tradisional atau caranya sendiri). Pengguna dari perancangan ini memerlukan ruang yang dapat digunakan sebagai media berinteraksi dan melakukan brainstorming serta berkolaborasi. Seperti halnya yang disampaikan Florida "diservitas dan kebutuhan menarik talenta untuk datang". Maka dibutuhkannya Communal Space yang memiliki aspek fungsional, estetik, interaksi sosial, bertukar pikiran, mampu mengakomodasi interaksi antara berbagai kelompok sosial dan etnis. Berdasarkan Composing Architecture and Interior Design by Simos Vamvakidis menyatakan area pada bagian tengah sebuah denah perancangan akan menjadi pusat perhatian atau dengan kata lain untuk mengorganisasikan sebuah ruang maka diperlukan elemen utama yang diposisikan pada pusat ruangan. Pada perancangan pada Communal space juga menerapkan teori yang disampaikan oleh Simos Vamvakidis mengenai Collective Space, dapat dikatakan Collective Space dan Communal Space merupakan tipe ruangan yang memiliki tujuan sama, yaitu sebagai area atau ruang "space of pause" di dalam bangunan.
\end{abstract}

Kata kunci: communal space; creative hub; gen Z; composing space

\section{ABSTRACT}

"One of the things that must be considered by cities is reality as a talent to strengthen the economy, while diversity and the attractive need for talent to come" (Florida, 2005: 139). Based on the results of the survey in the form of questionnaires conducted on active adolescents (18-24) in Bandung, it can be concluded that teenagers are interested in interacting to meet their sausage needs. Users approved in this design are Gen $Z$ in productive age (teenagers). Generation $Z$ at this age has characters who are more out of focus, multitasking, more individual, think more openly, more interested in being facilitated, more reliable, having more efficient ways (non-traditional or can be used alone). Users of this design need space that can be used as a medium of collaboration and brainstorming and collaborating. As exciting as it was conveyed Florida "diversity and interesting needs of talent to come". Then Communal Space Required which has functional, aesthetic aspects, social interaction, exchange of ideas, is able to accommodate interactions between various social and ethnic groups. Based on the Arrangement of Architecture and Interior Design by Simos Vamvakidis stating the area in the middle of the design plan will be the center of attention or other words to organize a space so that the elements positioned at the center of the room are needed. In the Communion Room Design Room also applies the theory conveyed by Simos Vamvakidis regarding Collective Space, it can be agreed that Collective Space and Communal Space are the types of rooms that have the same purpose, namely as "Space to Pause" in the building. Keyword: communal space; creative hub; gen Z; composing space 


\section{PENDAHULUAN}

"Salah satu hal yang harus diperhatikan oleh kota adalah kenyataan bahwa talenta menguatkan ekonomi, sedangkan diservitas dan kebutuhan menarik talenta untuk datang" (Florida, 2005:139). Bedasarkan Enabling Space: Mapping Creative Hubs in Indonesia, terdapat 3 jenis Hubs, yaitu Makerspace, Co-Working dan Creative Space. Dari tiga macam jenis tersebut harus memenuhi esensi yang ditawarkan. Menurut British Council dalam The Creative Hubs Report, Creative Hubs memiliki arti sebagai tempat atau ruang entah itu dalam bentuk fisik maupun virtual, yang menyatukan orang-orang untuk berkegiatan kreatif berkumpul sekaligus menyediakan ruang dan juga dukungan untuk menambah relasi, pengembangan bisnis, maupun keterlibatan masyarakat dalam sektor kratif, budaya dan teknologi. Berdasarkan definisi diatas dapat disimpulkan bahwasannya Creative Hubs merupakan sebuah ruang dimana kegiatan kreatif ditampung dan di dalamnya memiliki sarana untuk mengembangkan inovasi, ide, softskill dan hardskill yang dicapai melalui kegiatan kolaborasi.

Berdasarkan hasil survey dalam bentuk kuisioner yang ditujukan pada remaja aktif (18th24th) di kota Bandung, dapat disimpulkan bahwasannya seorang remaja memiliki ketertarikan dalam melakukan interaksi untuk memenuhi kebutuhan sosisalnya. Pengguna yang dimaksud pada perancangan ini adalah Gen Z pada usia produktivitas (remaja). Generasi Z pada usia tersebut memiliki karater antara lain lebih tidak fokus, multitasking, lebih individual, berfikiran lebih terbuka, tertarik untuk berinteraksi, lebih reliabilitas, memiliki cara yang lebih effisien (non-tradisional atau caranya sendiri).

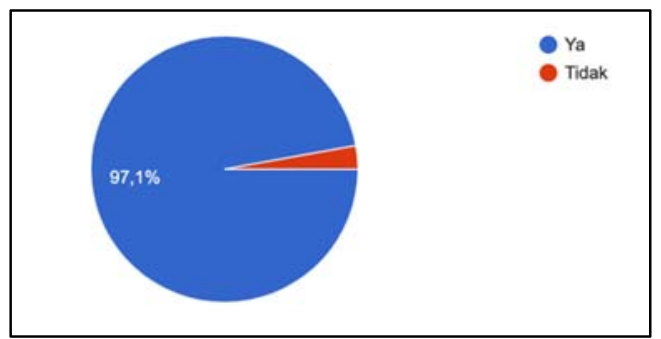

Diagram 1. Diagram Ketertarikan remaja Bertemu dengan Orang Baru Sumber: Dokumentasi Penulis (2019)

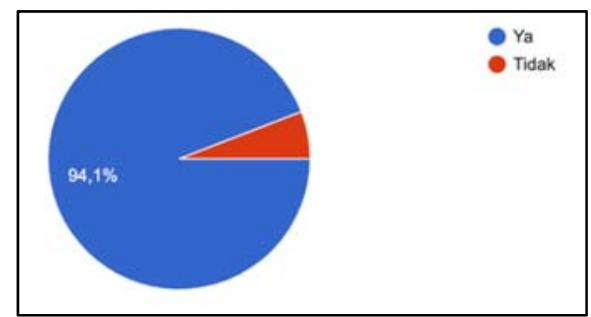

Diagram 2. Diagram Ketertarikan remaja Melakukan Kolaborasi dan Brainstorming Sumber: Dokumentasi Penulis (2019)

Dapat disimpulkan pengguna dari perancangan ini memerlukan ruang yang dapat digunakan sebagai media berinteraksi dan melakukan brainstorming serta berkolaborasi. Seperti halnya yang disampaikan Florida "diservitas dan kebutuhan menarik talenta untuk datang”. Maka dibutuhkannya Communal Space yang memiliki aspek fungsional, estetik, interaksi sosial, bertukar pikiran, mampu mengakomodasi interaksi antara berbagai kelompok sosial dan etnis. 


\section{METODE PENELITIAN}

Metode yang digunakan pada penelitian ini merupakan penggabungan dari metode kuantitatif dan kualitatif. Berikut metode yang dilakukan:

a. Metode kuantitatif dilakukan dengan cara pengumpulan data secara terukur melalui hasil kuisioner terkait fasilitas yang dibutuhkan pengguna.

b. Metode kualitatif berupa pengolahan data yang berisi analisa kajian literatur mengenai Creative Hub, karakter dari pengguna, dan Composing Space yang dapat diterapkan pada suasana dan fasilitas pada Communal Space.

\section{HASIL PENELITIAN DAN PEMBAHASAN}

Pada perancangan ini penempatan Communal Space terdapat pada bagian tengah denah lantai 1 yang dapat diakses melalui lobby dan 2nd entrance (dari area parking lot). Selain itu Communal space ini menghubungkan coffee shop, tangga menuju lantai 2, dan Co-Working, dalam artian Communal Space disini menghubungkan ruang satu dengan ruang lainnya. Berdasarkan Composing Architecture and Interior Design by Simos Vamvakidis menyatakan area pada bagian tengah sebuah denah perancangan akan menjadi pusat perhatian atau dengan kata lain untuk mengorganisasikan sebuah ruang maka diperlukan elemen utama yang diposisikan pada pusat ruangan. Pada perancangan pada Communal space juga menerapkan teori yang disampaikan oleh Simos Vamvakidis mengenai Collective Space, dapat dikatakan Collective Space dan Communal Space merupakan tipe ruangan yang memiliki tujuan sama, yaitu sebagai area atau ruang "space of pause" di dalam bangunan.

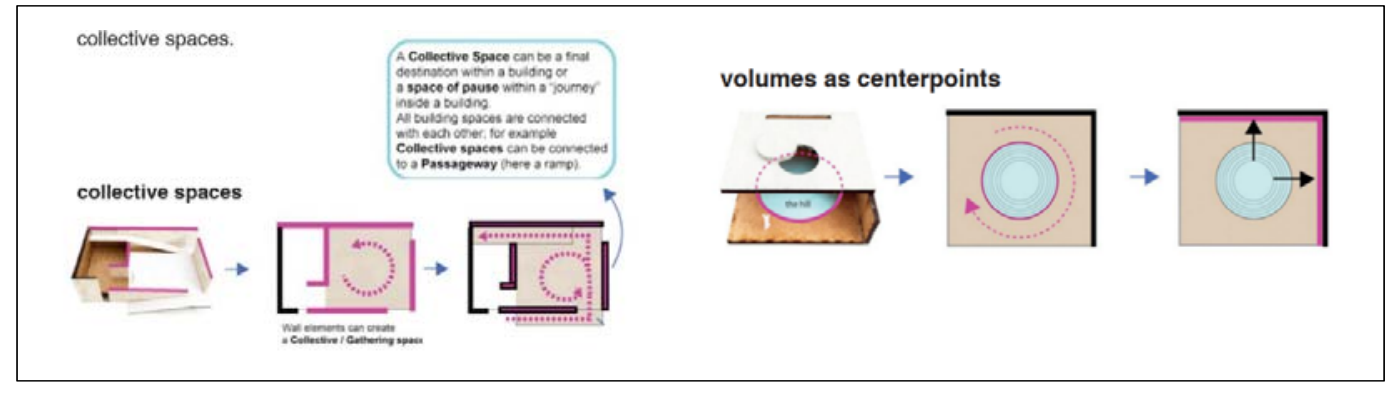

Gambar 1. Collective Space \& Volume as Centerpoints

Sumber: Composing Architecture and Interior Design by Simos Vamvakidis pg,52-53 (2018)

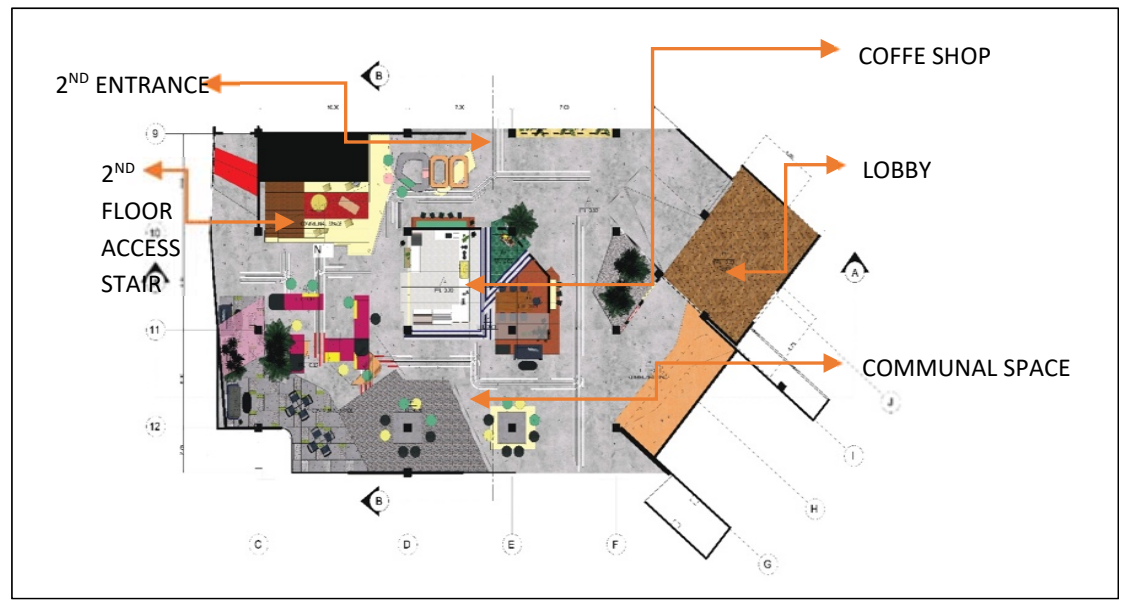

Gambar 2. Layout Communal Space

Sumber: Dokumentasi Penulis (2019) 


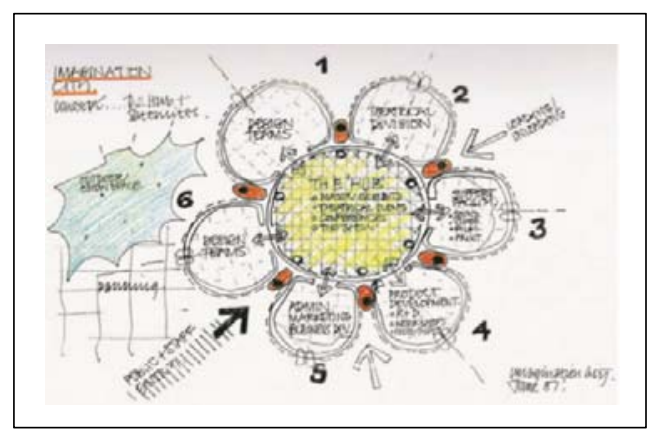

Gambar 3. Pola Sirkulasi Radial

Sumber: Ian Higgins Spatial Strategies for Interior pg.64 (2015)

\section{KESIMPULAN}

Pada perancangan Communal Space harus memperhatikan target pengguna yang akan dituju, karena hal ini mempengaruhi bagimana perancangan itu akan dirumuskan, dari segi tematiknya hingga konsep kemudian segi teknisnya. Selain itu, aspek-aspek pada Communal Space merupakan kunci utama yang wajib diaplikasikan pada perancangan ini demi memenuhi kebutuhan dari pengguannya.

\section{DAFTAR PUSTAKA}

Adam, Aulia (Reporter) \& Qomariah, Nurul (Editor). (2017). Tirto.id.Selamat Tinggal Generasi Milenial, Selamat Datang Generasi Z. (Online). (https://tirto.id/selamattinggal-generasi-milenial-selamat-datang-generasi-z-cnzX, diakses 6 Juli 2019).

Beall, George. (2016). 8 Key Differences Between GEN Z and Milenialls. (Online). (https://www.huffpost.com/entry/8-key-differencesbetween_b_12814200?guccounter=1., diakses 8 Juli 2019).

British Council. (2017). Enabling Space: Mapping Creative Hub in Indonesia. Jakarta Pusat: Centre for Innovation Policy and Converance.

Florida, R. (2005). The Rise of The Creative Class. Wahington: Basic Books.

Higgins, Ian. (2015). Spatial Strategies for Interior. London: Laurence King Publishing Ltd.

Vamvakidis, Simos. (2018). Composing Architecture and Interior Design. London: Laurence King Publishing. 